\title{
Studies on the ultrastructure of a three-spurred fumeauxiana form of Anacamptis pyramidalis
}

\author{
Agnieszka K. Kowalkowska • Hanna B. Margońska • \\ Małgorzata Kozieradzka-Kiszkurno • \\ Jerzy Bohdanowicz
}

Received: 14 April 2011 / Accepted: 13 February 2012/Published online: 14 March 2012

(C) The Author(s) 2012. This article is published with open access at Springerlink.com

\begin{abstract}
Floral spurs are regarded as features affecting pollinator behaviour. Anacamptis pyramidalis is regarded as a deceitful, non-rewarding orchid species. In the form fumeauxiana, additional spurs occur on the lateral sepals. In this study we analyse micromorphological and ultrastructural floral features and suggest the mechanism of deception in A. pyramidalis and A. pyramidalis f. fumeauxiana. In f. fumeauxiana, the adaxial surface of the lip, the lip calli, the tips of the lateral sepals, the abaxial and adaxial epidermises of the lip spur, and the lateral sepal spur have a secretory function. Numerous stomata were observed on the abaxial surfaces of spurs and sepals. The characteristic features of the ultrastructure of osmophore cells were noted: dense cytoplasm with numerous profiles of ER, mitochondria, plastids with plastoglobuli and tubular structures, a large nucleus, lipid droplets, and vesicles fusing with the plasmalemma. The similarity of the floral morphology and anatomy, the flowering period, and pollinators of A. pyramidalis, A. pyramidalis f. fumeauxiana and Gymnadenia conopsea suggest a possible food-deceptive mechanism-imitation of nectar presence produced in the spurs of Gymnadenia.
\end{abstract}

A. K. Kowalkowska ( $\square) \cdot$ M. Kozieradzka-Kiszkurno •

J. Bohdanowicz

Department of Plant Cytology and Embryology,

University of Gdańsk, Kładki 24, 80-822 Gdańsk,

Poland

e-mail: dokakow@ug.edu.pl

H. B. Margońska

Department of Plant Taxonomy and Nature Conservation,

University of Gdańsk, Legionów 9, 80-441 Gdańsk,

Poland
Keywords Anacamptis pyramidalis $\cdot$ A. pyramidalis f. fumeauxiana - Gymnadenia conopsea . Orchidaceae . Ultrastructure · Food-deception

\section{Introduction}

Floral spurs are features affecting pollinator behaviour. Their important function of guiding pollinators to flowers is well known (van der Pijl and Dodson 1969; van der Cingel 1995). The spur generally forms at the base of the labellum in butterfly and moth-pollinated orchids. Sometimes (e.g. Disa, Satyrium, Plectophora) it may be duplicated or developed on other tepals. The occurrence of a spur is usually associated with a nectar reward. However, approximately one third of orchid species are regarded as deceitful (sexual, food, or brood site deception; van der Pijl and Dodson 1969; van der Cingel 1995; Neiland and Wilcock 1998; Cozzolino and Widmer 2005; Schiestl 2005; Tremblay et al. 2005; Cozzolino and Scopece 2008; Bell et al. 2009; Claessens and Kleynen 2009; Jersáková et al. 2009; Vereecken 2009). The presence of a spur, even if nectarless, noticeably increases the possibility of floral pollination in the orchids (e.g. Dactylorhiza majalis/Orchis latifolia) or in other species (van der Pijl and Dodson 1969; Nilsson 1988; Hodges and Arnold 1995).

The wild type of Anacamptis pyramidalis (L.) L.C. Rich. is regarded as a non-rewarding plant which attracts pollinators by deceit, by having a spur without nectar (Neiland and Wilcock 1994, 1998; Fritz and Nilsson 1996; Proctor et al. 1996; Cozzolino et al. 2001; Cozzolino and Widmer 2005). Several authors have also added that it is a sweet-scented orchid with a long spur pollinated by butterflies and moths (Darwin 1877; van der Pijl and Dodson 
1969; Cuddy 1993; van der Cingel 1995; Proctor et al. 1996). It is known that A. pyramidalis is an evolutionarily plastic species (del Prete et al. 1991). The only difference between form fumeauxiana and type species is the appearance of additional spurs on the lateral sepals. This type of mutation creating the feature in a new location on the organism (neoheterotopy) has been noted in Ophrys mammosa Desf. (Bateman and Rudall 2006). In this species the lower portions of the expanded lateral sepals form typical lip features.

It is worthy of note that in molecular clade $A$. pyramidalis is close to A. coriophora, A. sancta, and A. fragrans-species with traces of nectar in the spurs (Bell et al. 2009). A second important observation in four clades of Orchidinae the strong correlation between nectar presence and papillae on the abaxial (internal) epidermis of spurs (with some exceptions) and noticeable but weak correlation between striations and lack of nectar (Bell et al. 2009). In the wild type of $A$. pyramidalis, striations inside the spur and lack of nectar have been reported (Bell et al. 2009). Our previous research (Kowalkowska et al. 2010a, b) on the lateral sepal spur and lip spur A. pyramidalis f. fumeauxiana Marg. and Kowalk. (Margońska and Kowalkowska 2008; HOLO-UGDA-HBM, ISO-UGDA-HBM) showed that the adaxial (external) and abaxial (internal) epidermises are built of a single cell layer covered by the undulating cuticle (striations). We did not observe any nectar inside the spurs. Nonetheless, the appearance of additional spurs developed on lateral sepals and unexpected secretory features of both spurs (lip and lateral sepal), especially on the inner epidermis, led us to study more precisely the ultrastructure of the form and the type species. The objectives of the work discussed in this paper were:

- to determine features of the ultrastructure of floral parts in the form and the type species; and

- to propose a hypothesis of food-deception (imitation of nectar presence) between Gymnadenia conopsea (as a model) and $A$. pyramidalis (as a mimic).

\section{Materials and methods}

Samples for study of the ultrastructure of A. pyramidalis $\mathrm{f}$. fumeauxiana were collected from plants at anthesis in June 2007 (Fig. 1a). Plants of the form fumeauxiana had been transplanted from the Soral area (village SE of Geneva, Switzerland) to the Les Conservatoire et Jardin Botaniques de la Ville de Genève in April/May. Samples of the typeform were collected at anthesis in June 2007 and 2008 from the Soral area, Rhone Valley, and the Les Conservatoire et Jardin Botaniques. The ultrastructure figures presented are from studies of the form fumeauxiana; in our opinion, however, after having obtained the same cytochemical results from wild species, the ultrastructures of these are similar.

The floral material was fixed for $4 \mathrm{~h}$ at room temperature in glutaraldehyde $(2.5 \% \mathrm{GA})$ and paraformaldehyde (2.5\% PFA) in cacodylate buffer $(0.05 \mathrm{M}, \mathrm{pH} 7.0)$. The material was post-fixed overnight in $1 \% \mathrm{OsO}_{4}$ in cacodylate buffer in a refrigerator and then rinsed in the buffer. After $1 \mathrm{~h}$ in $1 \%$ uranyl acetate in distilled water, the material was dehydrated with acetone and embedded in Spurr's resin. Ultrathin sections were cut on a Sorvall MT 2B ultramicrotome with a diamond knife and contrast stained with uranyl acetate and lead citrate. The sections were examined in a Philips CM 100 transmission electron microscope. For scanning electron microscopy (SEM), the samples were dehydrated in an ethanol series, dried by the critical point method, coated with gold, and then observed in a Philips XL-30 SEM. Samples were prepared in accordance with procedures described elsewhere (Kowalkowska and Margońska 2009; Kozieradzka-Kiszkurno and Bohdanowicz 2010; Kozieradzka-Kiszkurno et al. 2011).

\section{Results}

Lip surface

The adaxial surface of the three-lobed lip was covered by cone-shaped papillae (Fig. 1b, c). On the margins of the lip the papillae diminished to flat cells (Fig. 1b). The cuticle on each cell was ridged and at the top of papillae the pores occurred (Fig. 1c). Some remains of secreted substances on the adaxial lip surface were visible (Fig. 1c, d). The heterogeneous cell wall of the papillae was covered by a thick and ridged cuticle (Fig. 1d) consisting of the reticulate cuticle layer and the amorphous cuticle proper (Fig. 1d; terminology after Riederer and Müller 2006). The irregularity of the plasmalemma of the adaxial and abaxial epidermis was visible and the vesicles (some of them coated) occurred close to or connected with the plasmalemma (Fig. 1d, e). Between cells the plasmodesmata were observed (Fig. 2a). In a dense, parietal layer of cytoplasm (Figs. 1d, 2a, b), numerous mitochondria, the abundant profiles of smooth and rough ER, and a few microbodies with a paracrystalline core were present. The plastids contained numerous plastoglobuli, a large electron-dense body with dark and bright parts, and fine tubules (Fig. 2b). Highly vacuolated cells and the content of some of the vacuoles suggested their autophagic nature (the same as in Fig. 5e). 

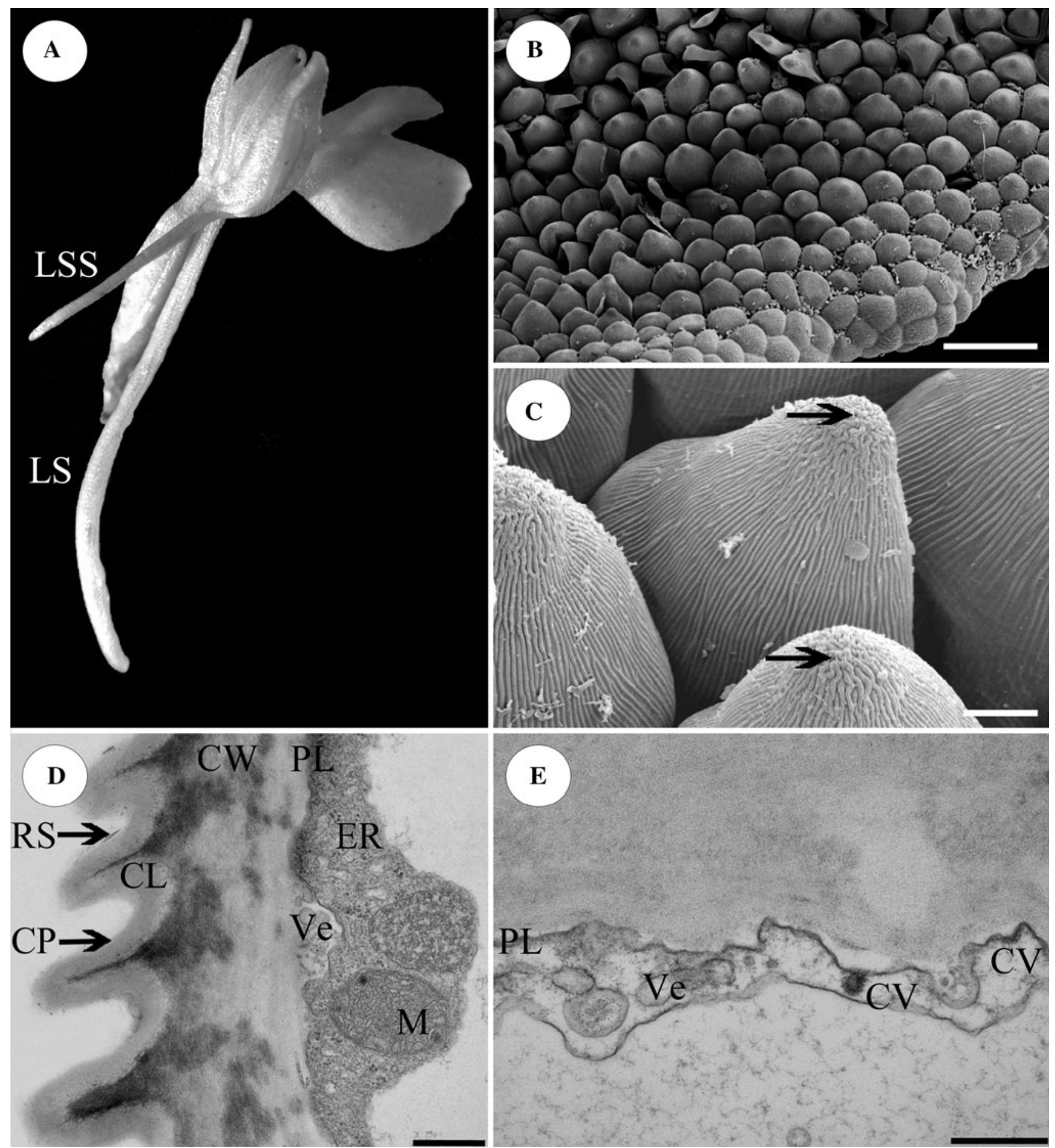

Fig. 1 Anacamptis pyramidalis f. fumeauxiana Marg. and Kowalk. a Flower with a lateral sepal spur $(L S S)$ and lip spur $(L S)$. Scanning electron microscope (SEM) images showing: b cone-shaped papillae on the adaxial lip surface diminishing to flat cells at the margins; c papillae with remains of secreted substances and pores in ridged cuticle (arrows). Transmission electron microscope (TEM) images showing: $\mathbf{d}$ the heterogeneous cell wall $(C W)$ of papillae, covered by

the thick cuticle built from the reticulate cuticle layer $(C L)$ and amorphous cuticle proper $(C P)$; on the surface are visible remains of secreted substances $(R S)$, the plasmalemma $(P L)$ irregularly formed with numerous vesicles $(V e)$, the parietal cytoplasm with mitochondria $(M)$, and profiles of the endoplasmic reticulum $(E R)$; e the vesicles $(\mathrm{Ve}$ ) (some of them coated, $\mathrm{CV}$ ) fused with plasmalemma (PL). Scale bars: $\mathbf{b}=100 \mu \mathrm{m} ; \mathbf{c}=20 \mu \mathrm{m} ; \mathbf{d}, \mathbf{e}=0.5 \mu \mathrm{m}$ 


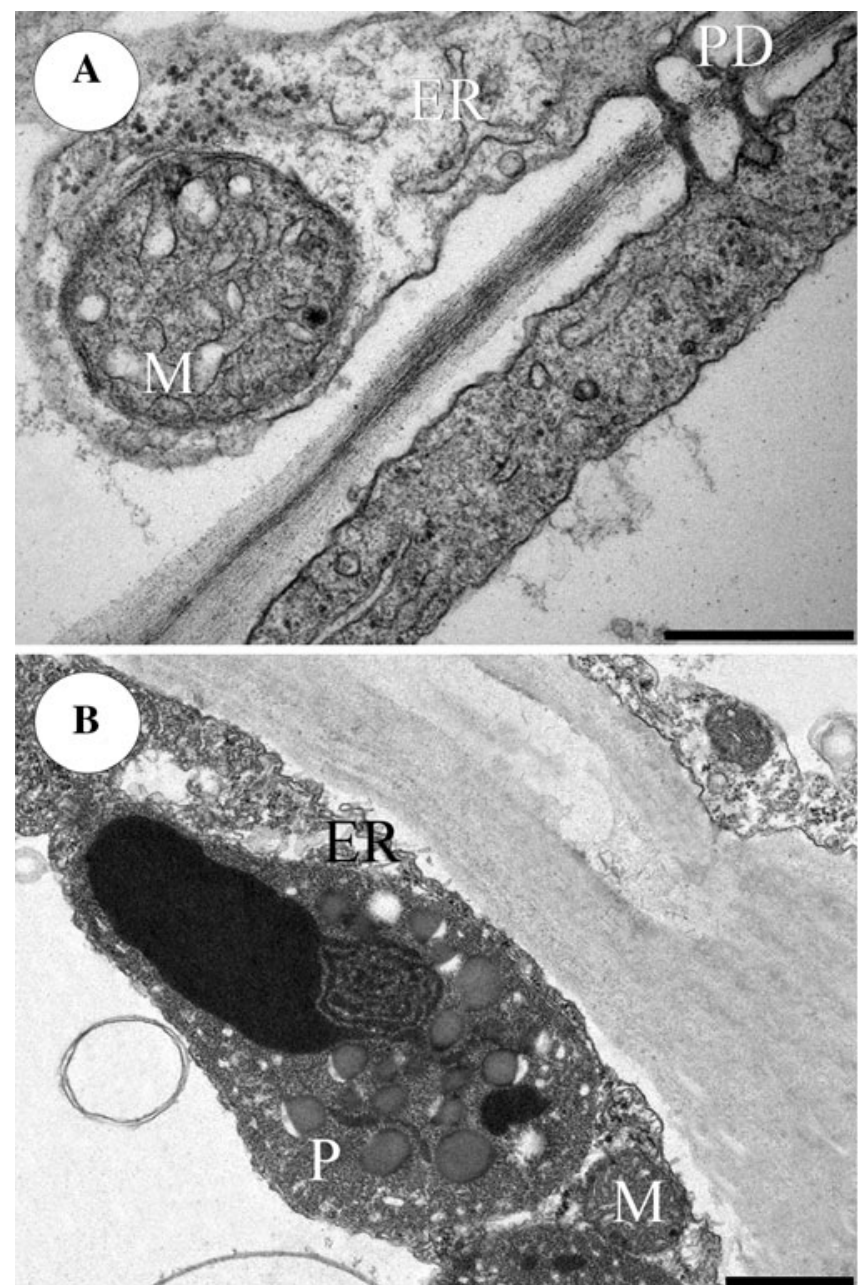

Fig. 2 TEM micrographs of the lip illustrating: a in the parietal layer of the cytoplasm visible mitochondria $(M)$ and profiles of endoplasmic reticulum $(E R)$, the cells connected through the plasmodesmata $(P D)$; b plastids $(P)$, with the large electron-dense body, dark and bright parts, and fine tubules), mitochondria $(M)$, and profiles of the endoplasmic reticulum $(E R)$. TEM images of lip calli showing: $\mathbf{c}$ the irregularly formed plasmalemma $(P L)$ with vesicles fusing with it $(V e)$, profiles of ER $(E R)$ in contact with mitochondria $(M)$ and lipid droplets $(L)$ and with plasmalemma $(P L)$ (black arrows); d the

\section{Lip calli}

The flat cells of the lip calli were covered by a heterogeneous cell wall and thick undulated cuticle with reticulate cuticle layer and amorphous cuticle proper (Fig. 2c), the same as described for the lip surface. In the vicinity of irregular plasmalemma, small vesicles forming part of the structure were observed (Fig. 2c). On the outer surface of the plasmalemma small patches of electron-dense material were observed in
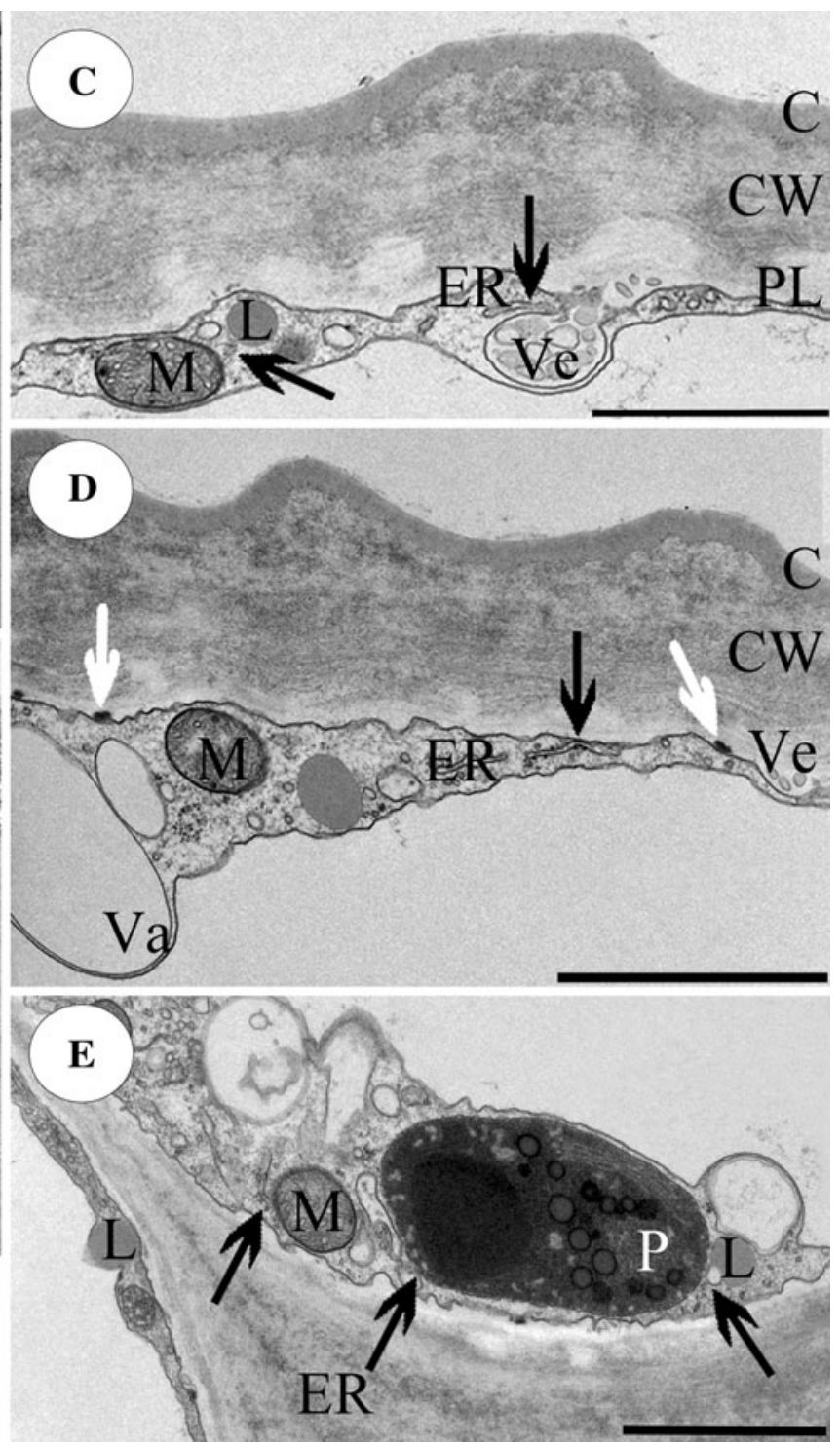

plasmalemma $(P L)$ with vesicles fusing with it $(V e)$, profiles of endoplasmic reticulum $(E R)$ in contact with the plasmalemma $(P L)$ (black arrow) and small patches of electron-dense material (white arrows), and numerous vacuoles (Va); e the oval-shaped plastid $(P)$ with large electron-dense body, plastoglobuli and tubules, abundant profiles of endoplasmic reticulum $(E R)$ in contact with mitochondria $(M)$, plastid $(P)$, and lipid droplet $(L)$ (black arrows). Scale bars: $\mathbf{a}=0.5 \mu \mathrm{m} ; \mathbf{b}=0.1 \mu \mathrm{m} ; \mathbf{c}-\mathbf{e}=2 \mu \mathrm{m}$

some places (Fig. 2d). The parietal layer of the cytoplasm (Fig. 2c, e), similarly as in the cells of the lip surface, contained abundant profiles of ER, mitochondria, a few plastids, and numerous vacuoles. The ER membranes were lying close to the plasmalemma (Fig. 2b), plastids, mitochondria, and lipid droplets (Fig. 2d, e). In the dense stroma of the ameboid and oval-shaped plastids, osmiophilic globules (plastoglobuli), intraplastidal membranes, and a large electron-dense body could be seen (Fig. 2e). 
Lip spur

TEM observations of the lip spur showed the heterogeneous structure of the cell wall on both (adaxial and abaxial) epidermises covered by cuticle with a reticulate cuticle layer (Fig. 3a). Also, small amounts of residues of secreted substances were observed; generally the residues seemed to be more abundant on the abaxial surface than on the adaxial (Fig. 3a), with the exception of a few cells. On the abaxial epidermis the cuticle was more wrinkled than on the adaxial (with the exception of some cells). Small invaginations of the plasmalemma (some of them coated) and numerous vesicles were observed (Fig. 3a, b). The neighbouring cells were joined by plasmodesmata (Fig. 3b). Highly vacuolated cells were visible. In some cells, the thin parietal layer of cytoplasm had degenerated to some extent, sometimes with numerous vacuoles, the same as observed in the lip callus (Fig. 2e). The profiles of the endoplasmic reticulum were smooth in some parts, covered by ribosomes in others (Fig. 3a, b). Profiles of ER were present in the vicinity of the plasmalemma, plastids, and mitochondria, with numerous cristae (Fig. 3b). In the cells of both epidermises the oval-shaped plastids (as in lip callus Fig. 2e), dictyosomes (Fig. 3a), and lipid droplets (illustrated in previous research, Kowalkowska et al. 2010a, b) were present.

\section{Other tepals}

The micromorphological features of other tepals-sepals and petals - revealed that only on the abaxial side of lateral sepals many stomata occurred (Fig. 4a, b). The ridged cuticle was visible at the tips and on the abaxial sides of lateral sepals (Fig. 4a, b) and the dorsal sepal (Fig. 4c, d). The surface of petals and the adaxial side of the dorsal sepal was formed of flat cells.

\section{Lateral sepals}

The cell wall on abaxial and adaxial epidermises was heterogeneous (Fig. 5a, c). Especially at the tip, the cuticle layer of the abaxial surface was highly reticulate, the cuticle proper was thin and amorphous (Fig. 5a). On the surface, more remains of secreted substances were visible than for previously described structures. The copious small vesicles, and some larger ones, were in close vicinity to the plasmalemma or growing into it (Fig. 5b). The dense cytoplasm (Fig. 5b, f) contained mitochondria, the profiles of SER and RER, a large nucleus, sometimes lipid droplets, plastids (with an electron-dense body, plastoglobuli, and the tubules). Unusually large vesicles with osmiophilic content joined with plasmalemma were observed (Fig. 5c).

\section{Lateral sepal spur}

In the cells of the lateral sepal spur, the thick cell wall, and the cuticle with reticulate cuticle layer and amorphous cuticle proper on both epidermises were observed (Fig. 5eh). As in the lip spur, undulation of the cuticle was generally more distinct on the abaxial epidermis than on the adaxial surface (with the exception of some cells). The cytoplasm was highly vacuolated. The central vacuole in some cells contained vesicles, probably autophagic

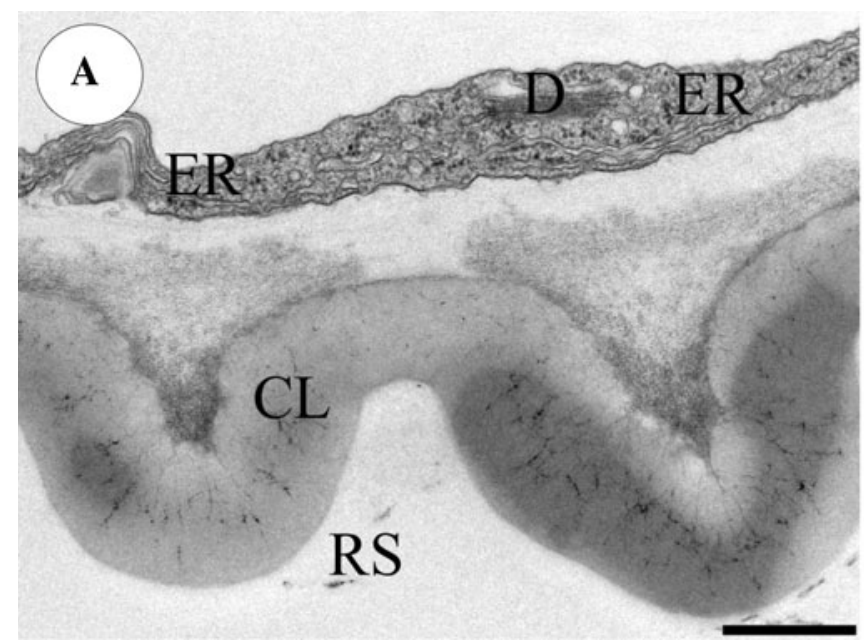

Fig. 3 TEM images of lip spur illustrating: a the adaxial epidermis: cuticle with reticulate cuticle layer $(C L)$, some remains of secreted substances $(R S)$, cytoplasm with dictyosomes $(D)$, and profiles of endoplasmic reticulum $(E R)$; b the abaxial epidermis: neighbouring

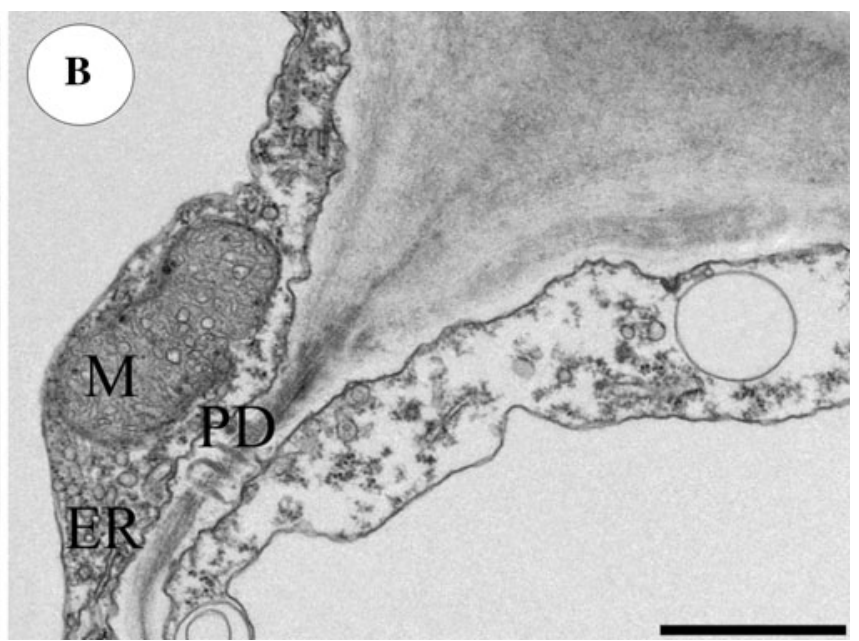

cells joined by plasmodesmata $(P D)$, mitochondria $(M)$, and profiles of the endoplasmic reticulum (ER). Scale bars: $\mathbf{a}=1 \mu \mathrm{m}$; $\mathbf{b}=0.5 \mu \mathrm{m}$ 

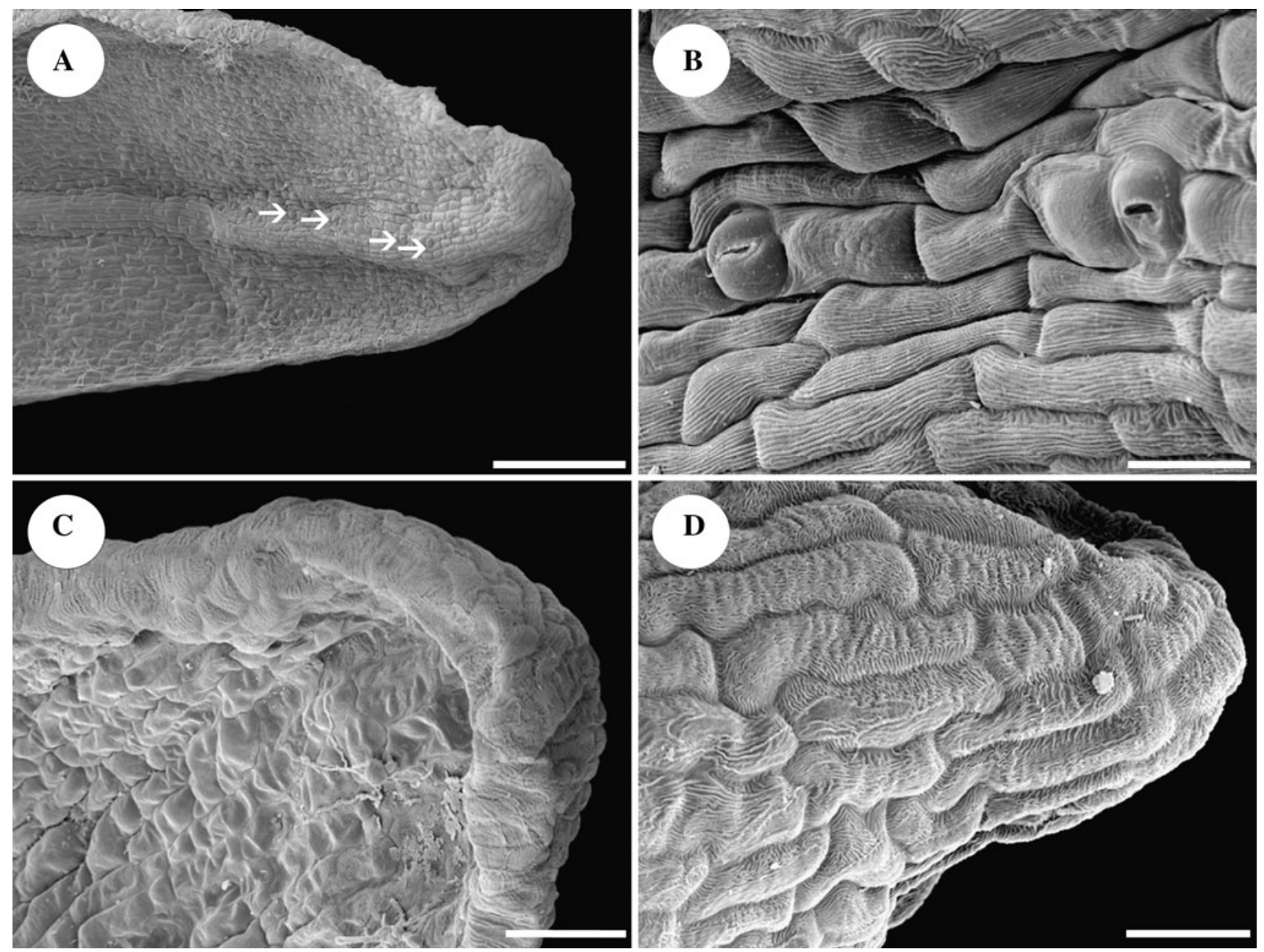

Fig. 4 SEM images of sepals. Lateral sepal: a abaxial side with numerous stomata (arrows), b magnification of a, Dorsal sepal: $\mathbf{c}$ adaxial side, the ridged cuticle on cells at the top of the sepal, $\mathbf{d}$ abaxial side, the ridged cuticle on cells. Scale bars: $\mathbf{a}=500 \mu \mathrm{m} ; \mathbf{c}=100 \mu \mathrm{m} ; \mathbf{b}, \mathbf{d}=50 \mu \mathrm{m}$

(Fig. 5e). Also large vesicles fusing with the vacuole were visible. Different levels of cell degeneration were also observed (Fig. 5e, h). The dense cytoplasm contained numerous profiles of ER, mitochondria, and some lipid droplets (Fig. 5e-g). In the oval-shaped plastids (Fig. 5e), plastoglobuli, tubules, and a large electron-dense body in the centre were visible. The plastids were often near the profiles of ER and lipid droplets (Fig. 5e). Small invaginations of the plasmalemma were frequently detected (Fig. 5e-g). In several cells of both epidermises in the cytoplasm, microbodies with paracrystalline core were present (Fig. 5f, g).

Spurs in f. fumeaxiana and typical form

In f. fumeauxiana on both spurs (lip and lateral sepal) numerous stomata were present close to the base. There were no noticeable stomata on the spur surface in the typical form.

\section{Discussion}

These observations of ultrastructure revealed that the adaxial (external) surface of the lip, the lip calli, the apices of the lateral sepals, and the lip and lateral sepal spurs have a secretory function. The possible explanation of the secretory activity is that the sepals' apices and lip surface may emit a fragrance in a diffusive manner. Scent may be produced by an undifferentiated epidermis, when the fragrances are emitted by diffusion (Mazurkiewicz 1913), or by osmophores - floral parts with glandular characteristics (Stern et al. 1987; Vogel 1990; Wiemer et al. 2008). The term "osmophore" was reintroduced by Vogel (1962), first reported in Arum italicum by Arcangeli (1883). The osmophores can be found within the whole inflorescence, but usually on the adaxial side of tepals and have a bullate, conical, rugose, pileate, or papillate epidermis (Vogel 1962; Pridgeon and Stern 1985; Stern et al. 1987; Curry 1987; Curry et al. 1988, 1991; Davies and Turner 2004; 
reviewed by Dudareva and Pichersky 2006). Maximum scent emission is correlated with the pollinators' activity, e.g. the fragrance of Cirrhopetalum graveolens is more intense during the day (Jongejan 1994). The different parts of one flower may produce diverse odours, creating odour guides ("Duftmal"). The role of odour guides is analogous with nectar guides (Lex 1954; reviewed by Vogel 1990), e.g. the two heterogeneous osmophore types in Mastigion ornatissimum (/C. ornatissimum): the distal tail-like parts of the lateral sepals produce an odour of cod-liver oil whereas the lip emits a trimethylamine-like odour (van der Cingel 1995). The osmophores in Orchidaceae release the fragrances in a liquid form, but they are not collected in large quantities because of their cytotoxicity. Volatiles, which may be mixtures of many components, are produced and released from time to time (Vogel 1990). The ultrastructure of osmophore tissue is characterized by highly enlarged nuclei compared with cells of closely placed tissue and a dense cytoplasm (Stern et al. 1987; Vogel 1990). Transmission electron microscopy (TEM) observations showed that in cells an abundant rough or smooth endoplasmic reticulum (ER), mitochondria, sometimes dictyosomes, and lipid droplets are present (Vogel 1962, 1990; Pridgeon and Stern 1985). In comparison with studies of the ultrastructure of G. conopsea (Stpiczyńska 2001) and Platanthera bifolia (Vogel 1990), the tissue is not particularly modified. The lip surface is papillate-the same as the osmophore in G. conopsea. Stomata were observed on the adaxial epidermis of the lip spur and the lateral sepal spur in f. fumeuaxiana and on the tips of lateral sepals. This is a feature of osmophores, but also nectaries (Evert 2006). The characteristic cells' features, for example dense cytoplasm with numerous profiles of ER, mitochondria, vesicles fusing with plasmalemma, a large nucleus, and lipid droplets, were described, as in other fragrant orchids (Stern et al. 1987; Curry et al. 1988; Vogel 1990; Stpiczyńska 1993, 2001).

The polymorphic plastids with electron dense stroma containing plastoglobuli and tubular structures, were typical of those of osmophore plastids (Stpiczyńska 2001), likewise in the orchid nectaries (Figueiredo and Pais 1992; Stpiczyńska 1997, 2003). The lack of starch grains in plastids, similarly to Cypripedium (Swanson et al. 1980) and Gymnadenia (Stpiczyńska 2001), was an important, rarely occurring feature. Starch-less plastids are believed to secrete lipid-soluble odours, for example monoterpenes (Fahn 1988). The hypothesis of plastid involvement in fragrance synthesis, because of the close vicinity of plastoglobuli and intraplastidal membranes and the plastid envelope and SER, has been broadly discussed by many researchers (Bosabalidis and Tsekos 1982; Curry 1987; Pais and Figueiredo 1994; Stpiczyńska 1997). In form fumeauxiana the numerous profiles of ER were in close vicinity and in contact with plastids. Bosabalidis and Tsekos (1982) explained that the connection of equivalent structures to plastids, joined with the ER, was the trait of volatile substances in Citrus secretory cells. In the osmophore cells of Stanhopea (Curry et al. 1988) the smooth endoplasmic reticulum (SER) was, furthermore, responsible for transport and/or synthesis of terpenoids. The proximity of SER and plastids were also pointed out in studies of the ultrastructure of the nectary spur of Limodorum abortivum (Pais and Figueiredo 1994) and P. bifolia (Stpiczyńska 1997). A dense osmiophilic material and tubular structures had been reported in plastids occurring in the nectaries of other orchid species (Pais and Figueiredo 1994; Stpiczyńska and Matusiewicz 2001; Stpiczyńska et al. 2004, 2005) and from glandular trichomes involved in terpenoid synthesis (Cheniclet and Carde 1985; Turner et al. 2000), in which the plastids were also in close association with ER.

A feature which might be indicative of osmophore function was the presence of lipid droplets in the cytoplasm, which were regarded as physical equivalents of production of volatiles (Swanson et al. 1980; Pridgeon and Stern 1983; Curry et al. 1988).

Numerous vesicles were present underneath the plasmalemma, which could indicate both transport of volatile substances and nectar (Fahn 1988). The invaginations of the plasmalemma containing visible vesicles in f. fumeauxiana were probably substances' migration. Afterward, through the cell wall, they cross the surface through the pores, similarly to granulocrine secretion (Curry et al. 1991), which was described for Restrepia (Pridgeon and Stern 1983) and G. conopsea (Stpiczyńska 1997). In the cells of lip calli small patches of electron-dense material in plasmalemma could be compared with the osmiophilic globules in the osmophore cells of Restrepia. The globules physically aggregated close to plasmalemma and then ruptured the cuticle (Pridgeon and Stern 1983), which has been described as granulocrine secretion. An electron-dense amorphous material present at anthesis on the outer surface of the cuticle was observed in Restrepia. Pridgeon and Stern (1983) suggested that it may comprise the scent compounds. Stpiczyńska (1997) explained the role of secretory vesicles in $G$. conopsea as releasing volatiles, in all probability by granulocrine secretion. Under the pressure of accumulated substances, the cuticle ruptures (Curry et al. 1991). In some orchids, on osmophore surfaces, the volatile compounds were visible as exudates (Vogel 1962; Williams et al. 1985). Accumulation of residues (in meagre amounts, however) was visible on the surfaces; this has also been observed for Stanhopea (Stern et al. 1987; Vogel 1990) but not noticed for Gymnadenia (Stpiczyńska 1997). Rothe (1974) claimed that microbodies also are involved in the production of 


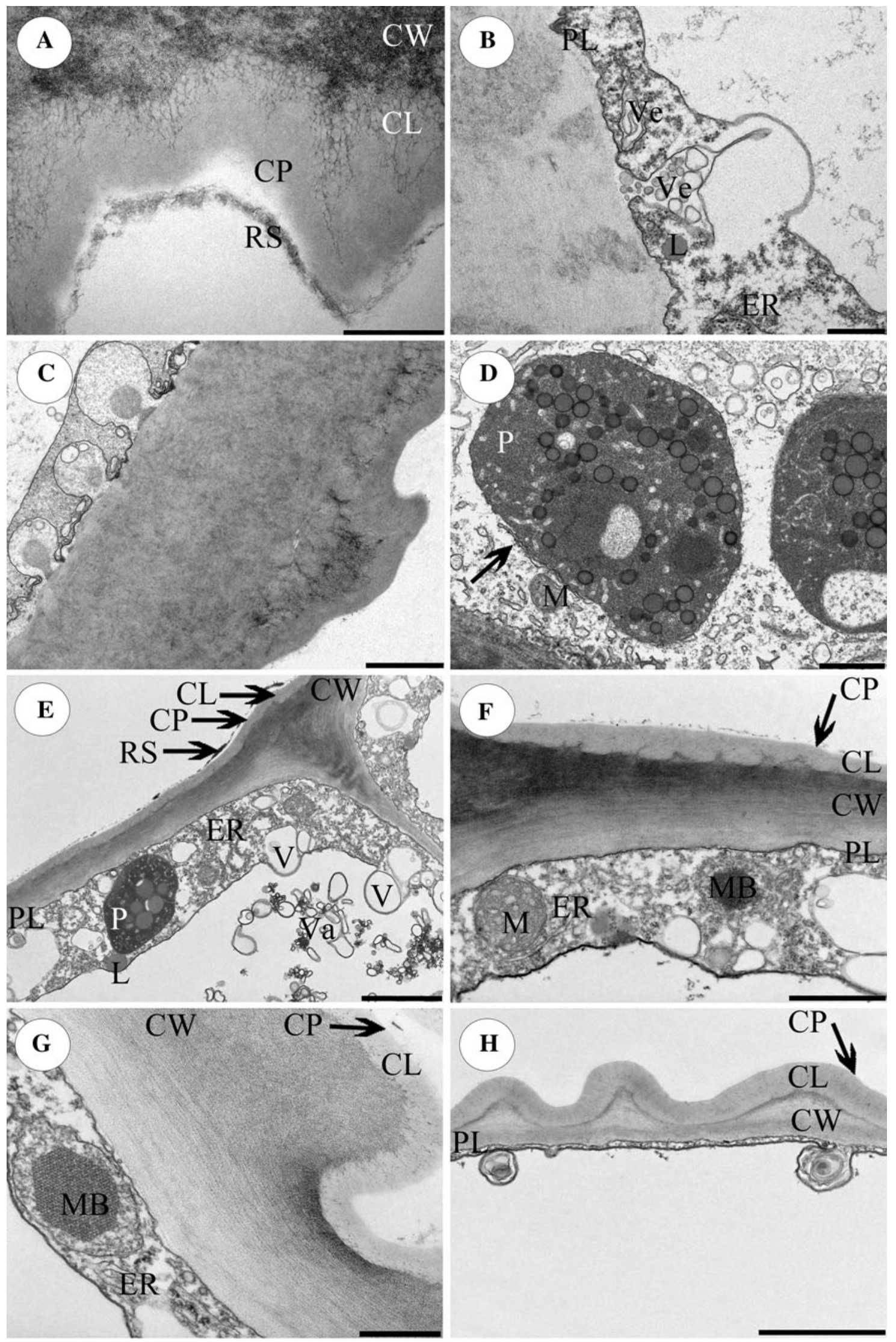


4 Fig. 5 TEM images of lateral sepals displaying: a the heterogeneous cell wall $(C W)$, highly reticulate cuticle layer $(C L)$, thin and amorphous cuticle proper $(C P)$, large amounts of remains of secreted substances $(R S)$; b numerous vesicles $(V e)$ connected to the plasmalemma $(P L)$, profiles of the endoplasmic reticulum $(E R)$ and lipid droplet $(L)$; $\mathbf{c}$ large vesicles with osmiophilic content joined to the plasmalemma $(P L)$; d plastid $(P)$ with electron-dense body, plastoglobuli, and inner tubules, mitochondria $(M)$, profiles of ER in contact with plastid (black arrow). TEM images illustrating features of lateral sepal spur: $\mathbf{e}-\mathbf{h}$ : the thick cell wall $(C W)$, reticulate cuticle layer $(C L)$, amorphous cuticle proper $(C P)$, remains of secreted substances $(R S)$, plasmalemma $(P L)$, mitochondria $(M)$, profiles of endoplasmic reticulum $(E R)$, and lipid droplet $(L)$. Note: e the central autophagic vacuole with inner vesicles $(V a)$ and vesicles $(V)$ fusing with it, the plastid $(P)$ with plastoglobuli, the tubules, and the large electrondense body; f, $\mathbf{g}$ the microbodies $(M B)$ with paracrystalline core; $\mathbf{h}$ the degenerated cytoplasm. Scale bars: $\mathbf{a}, \mathbf{b}, \mathbf{g}=0.5 \mu \mathrm{m}$; $\mathbf{c}$, $\mathbf{h}=2 \mu \mathrm{m} ; \mathbf{d}=0.1 \mu \mathrm{m}, \mathbf{e}, \mathbf{f}=1 \mu \mathrm{m}$

fragrant components. A few microbodies were noted in Anacamptis.

In our opinion, A. pyramidalis f. fumeauxiana and also its type-form are morphologically and anatomically similar to G. conopsea. G. conopsea is a more common species than A. pyramidalis (Landolt 1977; Reinhard et al. 1991), but both occur often in similar habitats. Moreover, in many localities in Switzerland (including Geneva), the flowering periods of both species are similar (from Mid-May to MidAugust). The same insects are observed on A. pyramidalis and $G$. conopsea flowers and hybrids between the both species are well known (e.g. X Gymnanacamptis anacamptis (F.H. Wilms) Asch. and Graebn.). In a phylogenetic tree based on an internal transcribed spacer (ITS) both species are distantly related (Bateman et al. 2003). We would, therefore, like to propose the hypothesis of a fooddeception mechanism between flowers of $G$. conopsea (as a rewarding model) and $A$. pyramidalis (as a non-rewarding mimic) according to Batesian floral mimicry. Both species have psychophilous flowers with diurnal anthesis, a horizontal landing place, pleasant odour (if present-fresh), simple nectar guides, nectar (or, in A. pyramidalis, its imitation) contained in long, narrow tubes, non-protruding gynostemium, and erect flowers (characters after van der Pijl and Dodson 1969). The scent of G. conopsea, if noted, is strong, but the scent of $A$. pyramidalis is slightly sweet or sometimes not noticeable. That from some $G$. conopsea populations is volatile ( $G$. conopsea densiflora), for some there is no noticeable fragrance (G. conopsea s.s.) (Landolt 1977; Reinhard et al. 1991; Landolt et al. 2010). The function of these features may be to imitate nectar presence. Variation in fragrance is often observed for deceptive orchids (Schiestl 2005) and odour complexity may be less than for the model species (Raguso 2004, after Wiemer et al. 2008).

To prove these hypotheses, more research on A. pyramidalis and its form are required, especially floral fragrance analysis (SPME) and comparative analysis with the scent of $G$. conopsea. Studies of pollinators' behaviour are also required. By publishing our results we wish to draw attention to problems with the Anacamptis populations.

Acknowledgments This work was supported by the University of Gdańsk (DS./L150-4-0128-1) and by the National Science Centre in Poland (5804/B/PO1/2010/39). Hanna B. Margońska is grateful to the Curator of the Conservatoire et Jardin Botaniques de la Ville de Geneve and to the keeper of its scientific library, for hospitality during her visits. We are grateful to Nicolas Fumeaux, Dr Alain Chautems, and Dr Cyrille Latour for their assistance during studies on Anacamptis. Agnieszka K. Kowalkowska used the Database of Orchid Ultrastructure (DOUL), and Hanna B. Margońska used the Archivum Orchidalium database.

Open Access This article is distributed under the terms of the Creative Commons Attribution License which permits any use, distribution, and reproduction in any medium, provided the original author(s) and the source are credited.

\section{References}

Arcangeli DIG (1883) Osservazioni sull impollinazione in alcune aracee. Nuovo Gior Bot Ital 7:72

Bateman RM, Rudall PJ (2006) The Good, the Bad, and the Ugly: using naturally occurring terata to distinguish the possible from the impossible in orchid floral evolution. Aliso 22:481-496

Bateman RM, Hollingsworth PM, Preston J, Luo Y-B, Pridgeon AM, Chase MW (2003) Molecular phylogenetics and evolution of Orchidinae and selected Habenariinae (Orchidaceae). Bot J Linn Soc 142:1-40

Bell AK, Roberts DL, Hawkins JA, Rudall PJ, Box MS, Bateman RM (2009) Comparative micromorphology of nectariferous and nectarless labellar spurs in selected clades of subtribe Orchidinae (Orchidaceae). Bot J Linn Soc 160:369-387

Bosabalidis A, Tsekos I (1982) Ultrastructural studies on the secretory cavities of Citrus deliciosa Ten. I. early stages of the gland cell differentiation. Protoplasma 112:55-62

Cheniclet C, Carde J-P (1985) Presence of leucoplasts in secretory cells and of monoterpenes in the essential oil: a correlative study. Isr J Bot 34:219-238

Claessens J, Kleynen J (2009) The flower of the European orchid: form and function. Published by the authors, Geulle

Cozzolino S, Scopece G (2008) Specificity in pollination and consequences for postmating reproductive isolation in deceptive Mediterranean orchids. Trans Royal Soc B 363:3037-3046

Cozzolino S, Widmer A (2005) Orchid diversity: an evolutionary consequence of deception? Trends Ecol Evol 20(9):487-494

Cozzolino S, Aceto S, Caputo P, Widmer A, Dafni A (2001) Speciation processes in Eastern Mediteranean Orchis s.l. species: Molecular evidence and the role of pollination biology. Isr $\mathbf{J}$ Plant Sci 49:91-103

Cuddy JC (1993) Fragrant Species List. Suppl. Orchid Species List. John Clark Cuddy, Washington

Curry KJ (1987) Initiation of terpenoid synthesis in osmophores of Stanhopea anfracta (Orchidaceae): a cytochemical study. Am J Bot 74:1332

Curry KJ, Stern WL, McDowell LM (1988) Osmophore development in Stanhopea anfracta and S. pulla (Orchidaceae). Lindleyana $3: 212$ 
Curry KJ, McDowell LM, Judd WS, Stern WL (1991) Osmophores, floral features, and systematics of Stanhopea (Orchidaceae). Am J Bot 78:610

Darwin C (1877) The different forms of flowers on plants of the same species. John Murray, London

Davies KL, Turner MP (2004) Morphology of floral papillae in Maxillaria Ruiz \& Pav. (Orchidaceae). Ann Bot 93:75

Del Prete C, Mazzola P, Miceli P (1991) Karyological differentiation and speciation in C. Mediterranean Anacamptis (Orchidaceae). Plant Syst Evol 174:115-123

Dudareva N, Pichersky E (2006) Biology of floral scent. CRC Press, Boca Raton

Evert RF (2006) External Secretory Structures. In: Evert RF (ed) Esau's plant anatomy: meristems, cells, and tissues of the plant body: their structure, function, and development. Wiley, USA, pp 447-472

Fahn A (1988) Secretory tissues in vascular plants. New Phytol 108:229-257

Figueiredo ACS, Pais MS (1992) Ultrastructural aspects of the nectary spur of Limodorum abortivum (L.) Sw. Orchidaceae. Ann Bot 70:325-331

Fritz A-L, Nilsson LA (1996) Reproductive success and gender variation in deceit-pollinated orchids. In: Lloyd DG, Barrett SC (eds) Floral biology. Chapman and Hall, New York, pp 319-338

Hodges SA, Arnold ML (1995) Spurring plant diversification: are floral nectar spurs a key innovation? Proc Royal Soc Lond B 262:343-348

Jersáková J, Johnson SD, Jürgens A (2009) Deceptive behaviour in pants II. food deception by plants: from generalized systems to specialized floral mimicry. In: Baluška F (ed) Plant-environment interactions, signaling and communication in plants, from sensory plant biology to active plant behavior. Springer-Verlag, Berlin, pp 223-246

Jongejan P (1994) Specializations in ways of attracting insects for pollination in the genus Bulbophyllum. In: Pridgeon AM (ed) Proc 14th World Orchid Conf. Edinburgh: HMSO, 383-388

Kowalkowska AK, Margońska HB (2009) Diversity of labellar micromorphological structures in selected species of Malaxidinae (Orchidales). Acta Soc Bot Pol 78(2):141-150

Kowalkowska AK, Margońska HB, Kozieradzka-Kiszkurno M (2010a) Comparative anatomy of the lip spur and additional lateral sepal spurs in a three-spurred form (f. fumeauxiana) of Anacamptis pyramidalis. Acta Biol Crac Series Bot 52(1):13-18

Kowalkowska AK, Margońska HB, Kozieradzka-Kiszkurno M, Bohdanowicz J (2010b) Comparative anatomy of the lip spur and additional lateral sepal spurs in a three-spurred form (f. fumeauxiana) of Anacamptis pyramidalis. In: EED Conference Paris, pp 92-93

Kozieradzka-Kiszkurno M, Bohdanowicz J (2010) Unusual electrondense dome associates with compound plasmodesmata in the embryo-suspensor of genus Sedum (Crassulaceae). Protoplasma 247:117-120

Kozieradzka-Kiszkurno M, Płachno BJ, Bohdanowicz J (2011) New data about the suspensor of succulent angiosperms: ultrastructure and cytochemical study of the embryo-suspensor of Sempervivum arachnoideum L. and Jovibarba sobolifera (Sims) Opiz. Protoplasma doi:10.1007/s00709-011-0297-y

Landolt E (1977) Flora indicativa Ökologische Zeigerwerte und biologische Kennzeichen zur Flora der Schweiz und der Alpen. 2. völlig neu bearbeitete und erweiterte Auflage der Ökologischen Zeigerwerte zur Flora der Schweiz

Landolt E, Bäumler B, Erhardt A, Hegg O, Klötzli F, Lämmler W, Nobis M, Rudmann-Maurer K, Schweingruber FH, Theurillat J-P, Urmi E, Vust M, Wohlgemuth T (2010) Flora indicativa Ökologische Zeigerwerte und biologische Kennzeichen zur Flora der Schweiz und der Alpen/Ecological indicator values and biological attributes of the flora of Switzerland and the Alps, 2nd edn. Editions des Conservatoire et Jardin botaniques de la Ville de Genève \& Haupt Verlag, Bern

Lex T (1954) Duftmale an Bluten. Zeit Vergl Physiol 36:212-234

Margońska HB, Kowalkowska AK (2008) Une nouvelle forme de Anacamptis pyramidalis (Orchidaceae). Richardiana 8(1):1-5

Mazurkiewicz W (1913) Über die Verteilung des ätherischen Öls im Blütenparenchym und über seine Lokalisation im Zellplasma. Zeitschrift des Allgemeinen Österreichischen Apotheker-Vereines 51:241-284

Neiland MRM, Wilcock CC (1994) Reproductive ecology of European orchids. In: Pridgeon AM (ed) Proc 14th World Orchid Conf. Edinburgh: HMSO, 138-147

Neiland MRM, Wilcock CC (1998) Fruit set, nectar reward, and rarity in the Orchidaceae. Am J Bot 85:1657-1671

Nilsson LA (1988) The evolution of flowers with deep corolla tubes. Nature 334:147-149

Pais MS, Figueiredo ACS (1994) Floral nectaries from Limodorum abortivum (L.) Sw. and Epipactis atropurpurea rafin. (Orchidaceae); ultrastructural changes in plastids during the secretory process. Apidologie 25:615-626

Pridgeon AM, Stern WL (1983) Ultrastructure of osmophores in Restrepia (Orchidaceae). Am J Bot 70(8):1233-1243

Pridgeon AM, Stern WL (1985) Osmophores of Scaphosepalum (Orchidaceae). Bot Gaz 146:115

Proctor M, Yeo P, Lack A (1996) The natural history of pollination. Harper Collins Publishers, London

Raguso RA (2004) Flowers as sensory billboards: progress towards an integrated understanding of floral advertisement. Curr Opin Plant Biol 7:434-440

Reinhard HR, Golz P, Peter R, Wildermuth H (1991) Die Orchideen der Schweiz und angrenzender Gebiete, 1st edn. Fotorotar AG, Neue Medien, Germany

Riederer M, Müller C (2006) Biology of plant cuticle, 1st edn. Blackwell, Oxford

Rothe GM (1974) Intracellular compartmentation and regulation of two shikimate dehydrogenase isoenzymes in Pisum sativum. Zeit Pflanzemphysiol 74:152-159

Schiestl FP (2005) On the success of a swindle: pollination by deception in orchids. Naturwissenschaften 92:255-264

Stern WL, Curry KJ, Pridgeon AM (1987) Osmophores of Stanhopea (Orchidaceae). Am J Bot 74:1323

Stpiczyńska M (1993) Anatomy and ultrastructure of osmophores of Cymbidium tracyanum Rolfe (Orchidaceae). Acta Soc Bot Pol 62:5-9

Stpiczyńska M (1997) The structure of nectary of Platanthera bifolia L. Orchidaceae. Acta Soc Bot Pol 1:5-7

Stpiczyńska M (2001) Osmophores of the fragrant orchid Gymnadenia conopsea L. (Orchidaceae). Acta Soc Bot Pol 70(2):91-96

Stpiczyńska M (2003) Nectar resorption in the spur of Platanthera chlorantha (Custer) Rchb. Orchidaceae-structural and microautoradiographic study. Plant Syst Evol 238:119-126

Stpiczyńska M, Matusiewicz J (2001) Anatomy and ultrastructure of spur nectary of Gymnadenia conopsea (L.) Orchidaceae. Acta Soc Bot Pol 4:267-272

Stpiczyńska M, Davies KL, Gregg A (2004) Nectary Structure and Nectar Secretion in Maxillaria coccinea (Jacq.) L.O. Williams ex Hodge (Orchidaceae). Ann Bot 93(1):87-95

Stpiczyńska M, Davies KL, Gregg A (2005) Comparative account of nectary structure in Hexisea imbricata (Lindl.) Rchb.f. (Orchidaceae). Ann Bot 95(5):749-756

Swanson ES, Cunningham WP, Holman RT (1980) Ultrastructure of glandular ovarian trichomes of Cypripedium caleolus and C. reginae (Orchidaceae). Am J Bot 67(5):784-789

Tremblay RL, Ackerman JD, Zimmerman JK, Calvo RN (2005) Variation in sexual reproduction in orchids and its evolutionary 
consequences: a spasmodic journey to diversification. Biol $\mathrm{J}$ Linn Soc 84:1-54

Turner GW, Gershenzon J, Croteau RB (2000) Development of the pellate glandular trichomes of peppermint. Plant Physiol 124:665-679

van der Cingel NA (ed) (1995) An atlas of Orchid Pollination. Balkema, Rotterdam

van der Pijl L, Dodson CH (1969) Orchid flowers. their pollination and evolution. University of Miami Press, Coral Gables

Vereecken NJ (2009) Deceptive behavior in plants. I. Pollination by sexual deception in orchids: a host-parasite perspective. In: Baluska $F$ (ed) Plant-environment interactions, signaling and communication in plants, from sensory plant biology to active plant behavior. Springer-Verlag, Berlin, pp 203-222
Vogel S (1962) Duftdrüsen im Dienste der Bestäubung. Über Bau und Funktion der Osmophoren. Akad Wiss Lit, Abh Math-Nat Kl 10:598-763

Vogel S (1990) The Role of Scent Glands in Pollination: On the Structure and Function of Osmophores. Amerind, New Delhi

Wiemer AP, Moré M, Benitez-Vieyra S, Cocucci AA, Raguso RA, Sérsic AN (2008) A simple floral fragrance and unusual osmophore structure in Cyclopogon elatus (Orchidaceae). Plant Biol (Stuttg) 11(4):506-514

Williams NH, Whitten WM, Pedrosa LF (1985) Crystalline production of fragrance in Gongora quinquenervis. Am Orchid Soc Bull 54:598-603 